\title{
Trichinella spiralis paramyosin activates mouse bone marrow-derived dendritic cells and induces regulatory $T$ cells
}

\author{
Kai Guo ${ }^{1,2+}$, Ximeng Sun ${ }^{1,2+}$, Yuan Gu ${ }^{1,2}$, Zixia Wang ${ }^{1,2}$, Jingjing Huang ${ }^{1,2}$ and Xinping Zhu ${ }^{1,2^{*}}$
}

\begin{abstract}
Background: Dendritic cells (DCs) are antigen-presenting cells that regulate T cell responses for many infectious diseases. The tissue-dwelling nematode Trichinella spiralis expresses paramyosin (TsPmy) not only as a structural protein but also as an immunomodulator to alleviate complement attack by binding to some host complement components. Whether TsPmy is involved in other immunomodulatory pathway and how TsPmy interacts with host DCs is still unknown.

Methods: Mouse bone marrow-derived DCs were incubated with recombinant TsPmy (rTsPmy) for activation. Maturation of DC was determined by the expression of surface markers CD40, CD80, CD86 and MHCll. The rTsPmy-pulsed DCs were co-incubated with $T$. spiralis-sensitized or naïve mouse $C D 4^{+} T$ cells to observe their activation on $T$ cells and polarizing regulatory T cells using flow cytometry. Cytokines were measured by enzyme-linked immunosorbent assays (ELISA).

Results: TsPmy was able to activate mouse bone marrow-derived DCs to semi-mature status characterized by expressing surface CD40 and CD86, but not CD80 and MHCII. The semi-mature TsPmy-pulsed DCs were able to stimulate T. spiralis-sensitized $C D 4^{+} T$ cells to proliferate. Incubation of TsPmy-pulsed DCs with naïve CD4 ${ }^{+}$splenocytes polarized the latter to $\mathrm{CD}^{+} \mathrm{CD}_{2} 5^{+} \mathrm{Foxp}^{+}$regulatory $\mathrm{T}$ cells. However, mice immunized with rTsPmy only induce the $\mathrm{CD}_{4}^{+} \mathrm{CD}_{25}{ }^{-} \mathrm{Foxp}^{+} \mathrm{T}$ cell population, associated with high level of IL-10, TGF- $\beta$ and IL-17A.

Conclusions: During T. spiralis infection, TsPmy plays an important role in modulating the host immune system by stimulating DCs to differentiate the $\mathrm{CD}^{+} \mathrm{T}$ cells to regulatory $\mathrm{T}$ cells, in addition to binding to components of the host complement cascade, as survival strategies to live in host.
\end{abstract}

Keywords: Dendritic cells, Trichinella spiralis, Paramyosin, Regulatory T cells

\section{Background}

Trichinellosis is a serious zoonotic parasitic disease caused by the infection of Trichinella spiralis through ingestion of meat contaminated with infective larvae. It is estimated that more than 11 million people could be infected with $T$. spiralis worldwide [1] and heavy infection can even causes death [2]. Trichinella spiralis is a tissue-dwelling parasitic nematode. During T. spiralis infection, the entire life-cycle is completed within the same host. After being ingested, the infective muscle

\footnotetext{
* Correspondence: zhuxping@ccmu.edu.cn

${ }^{\dagger}$ Equal contributors

'Department of Medical Microbiology and Parasitology, School of Basic Medical Sciences, Capital Medical University, Beijing 100069, China

${ }^{2}$ Research Centre of Microbiome, Capital Medical University, Beijing 100069, China
}

larvae develop to adult worms in the host intestine. The and cause a chronic infection [3]. How the Trichinella parasite maintains the chronic infection within the host without being recognized and attacked by the host's immune system remains unknown [4]. Understanding the mechanism underlying the immune evasion would greatly benefit the design of preventive/therapeutic vaccines or drugs to control the infection.

Paramyosin is not only a fibrillar protein exclusively found in invertebrates, but also a functional protein expressed on the surface of many helminths [5-7] that plays an important role as an immunomodulatory molecule 
to defend against host immune attack [8-10]. Paramyosin of $T$. spiralis (Ts Pmy) was cloned from the adult $T$. spiralis in a previous study [11]. Subsequent studies have identified that TsPmy binds to host complement components C8, C9 and $\mathrm{Clq}$ that interferes with the forming of complement membrane attack complex and protects parasite from being attacked by the host innate immune system [12-15]. Partial protective immunity against $T$. spiralis larval challenge was determined in $\mathrm{BALB} / \mathrm{c}$ mice immunized with recombinant TsPmy (rTsPmy) [16] and protective epitopes [17-19] or through RNAi [20]. Except for interfering with host complement system, whether TsPmy is involved in other immunomodulatory function is unknown.

Dendritic cells (DCs) are antigen presenting cells that play a pivotal role in the control and modulation of immune responses by initiating $\mathrm{T}$ cell responses and producing cytokines and other molecules that regulate adaptive immunity [21]. How TsPmy interacts with DC and subsequently impacts DC activation and function during T. spiralis infection is not understood.

In this study, we investigated the roles of TsPmy on DCs maturation and subsequent $\mathrm{T}$ cell polarization. The study herein demonstrated that TsPmy could activate bone marrow-derived mouse DCs and consequently promote the differentiation of $\mathrm{CD} 4^{+} \mathrm{T}$ cells to regulatory $\mathrm{T}$ cells (Tregs). The induction of Tregs by TsPmy through activated DCs during $T$. spiralis infection may inhibit the host immune response and play an important role in the survival of $T$. spiralis in infected host.

\section{Methods}

\section{Experimental animals}

Specific pathogen-free 6-8 week-old female BALB/c mice were purchased from the Laboratory Animal Services Center of the Capital Medical University (Beijing, China) and housed under specific pathogen-free conditions with humidity and temperature controlled (temperature of $20 \pm 2{ }^{\circ} \mathrm{C}$; humidity of $70 \pm 10 \%$ ). All animal protocols and husbandry were approved by Capital Medical University Institutional Animal Care and Use Committee (IACUC).

\section{Parasites and experimental infection}

The ISS 533 strain of T. spiralis was maintained in female ICR mice. Muscle larvae (ML) were received from the muscles of infected mice by previously described method of modified pepsin-hydrochloric acid digestion [17]. BALB/c mice were infected with 400 infective T. spiralis ML by oral gavage and immunized with recombinant TsPmy (rTsPmy) as described below.

\section{Antigen preparation}

The recombinant TsPmy with a His-tag at C-terminus was expressed in Baculovirus/insect cell Sf9 (Invitrogen, Carlsbad, CA, USA) and purified with Ni-affinity chromatography (Qiagen, Valencia, CA, USA). Lipopolysaccharide (LPS) (Sigma-Aldrich, St. Louis, MO, USA) was used as a positive control for immune response. Sf9 cell lysis proteins were used as non-relevant proteins control. All antigens were stored at $-80{ }^{\circ} \mathrm{C}$.

\section{Generation of dendritic cells}

DCs were generated from mouse bone marrow cells as described [22]. Briefly, bone marrow cells were obtained from BALB/c mice and cultivated in RPMI 1640 medium (Hyclone, Logan, UT, USA) supplemented with $10 \%$ foetal bovine serum (FBS; Thermo Fisher, Life Technologies, Carlsbad, CA, USA) and penicillin/ streptomycin at $37{ }^{\circ} \mathrm{C}, 5 \% \mathrm{CO}_{2}$ for $3 \mathrm{~h}$. After removing the suspended cells, the remaining adherent cells were cultured in RPMI 1640 medium containing growth factors of $10 \mathrm{ng} / \mathrm{ml}$ recombinant GM-CSF and $2 \mathrm{ng} / \mathrm{ml}$ IL-4 (Prospec, Rehovot, Israel) and 10 \% FBS for 6 days with replenishment of the same culture medium on Day 3 and Day 5. The immature DCs were harvested on Day 6 for further experiments.

\section{In vitro $D C$ activation}

The immature DCs produced above were stimulated with $\mathrm{r} T s$ Pmy $(10 \mu \mathrm{g} / \mathrm{ml})$, LPS $(2 \mu \mathrm{g} / \mathrm{ml})$ or PBS respectively in vitro for $48 \mathrm{~h}$. The stimulated cells were stained with APC-conjugated monoclonal antibody (mAb) to $\mathrm{CD} 11 \mathrm{c}$, the major marker of mature DCs [23], and $\mathrm{PE}$-conjugated $\mathrm{mAbs}$ to major histocompatibility complex II (MHCII), CD40, CD80 or CD86 respectively (BD Biosciences, San Jose, CA, USA). The cytokine levels in the culture supernatants were determined by the corresponding enzyme-linked immunosorbent assay (ELISA) kits according to the manufacturer's instructions (Dakewe Biotech, Shenzhen, China).

\section{Co-incubation of rTsPmy pulsed DCs with $T$. spiralis- sensitized $C D 4^{+} T$ cells}

To determine whether rTsPmy-pulsed DCs could activate T. spiralis-sensitized $\mathrm{CD}_{4}^{+} \mathrm{T}$ cells, the DCs pulsed with rTsPmy for $72 \mathrm{~h}$, and then were co-cultivated with $T$. spiralis-sensitized $\mathrm{CD} 4^{+} \mathrm{T}$ cells, the $T$. spiralis-sensitized $\mathrm{CD}^{+}{ }^{+} \mathrm{T}$ cells were obtained from the spleens of BALB/C mice infected with $400 \mathrm{~T}$. spiralis ML for 60 days using magnetic-activated cell sorting (MACS) with a mouse $\mathrm{CD}^{+} \mathrm{T}$ cell isolation kit (Miltenyi Biotec, Bergisch Gladbach, Germany). A total of $5 \times 10^{4}$ or $2.5 \times 10^{4}$ DCs were plated in each well of round-bottom 96-well plates and then co-cultivated with $5 \times 10^{5} \mathrm{~T}$. spiralis-sensitized $\mathrm{CD}^{+} \mathrm{T}$ cells stained with 5 -and 6-carboxyfluorescein diacetate succinimidyl ester (CFSE) (eBioscience, San Diego, CA, USA), in the presence of $5 \mu \mathrm{g} / \mathrm{ml}$ Concavalin-A (Con-A) (Sigma-Aldrich, St. Louis, MO, USA) which is a nonspecific stimulator for mouse T cells. Subsequently, 
the proliferation of $\mathrm{T}$ cells was measured by fluorescenceactivated cell sorting (FACS).

To determine the cytokine production, $5 \times 10^{4}$ DCs were plated in each well of round-bottom 96-well plates and co-incubated with $5 \times 10^{5} \mathrm{~T}$. spiralis-sensitized $\mathrm{CD} 4^{+}$ $\mathrm{T}$ cells for $36 \mathrm{~h}$, then supernatants were collected and cytokines measured by ELISA as described above.

\section{rTsPmy pulsed DCs/naïve $\mathrm{CD}^{+} \mathrm{T}$ cells co-incubation}

To assess the ability of $r T s$ Pmy-pulsed DCs on naïve $\mathrm{T}$ cell polarization, DCs were stimulated with $\mathrm{rTs}$ Pmy for $72 \mathrm{~h}$, and the naive $\mathrm{CD} 4^{+} \mathrm{T}$ cells were isolated from the spleens of healthy BALB/c mice by MACS using mouse $\mathrm{CD}^{+} \mathrm{T}$ cell isolation kit. Total $5 \times 10^{4} \mathrm{DCs}$ were plated in each well of round-bottom 96-well plates and co-incubated with $5 \times 10^{5}$ naïve $\mathrm{CD} 4^{+} \mathrm{T}$ cells. The co-incubated DCs/naive $\mathrm{T}$ cells were stimulated with $5 \mu \mathrm{g} / \mathrm{ml}$ platebound anti-CD3/anti-CD28 (Peprotech, NJ, USA) which delivers signal one and a costimulatory signal two without leading to early cell death for proliferated cells [24]. The co-incubation was continued at $37{ }^{\circ} \mathrm{C}$ for $36 \mathrm{~h}$ and cells were recovered for detecting the percentage of $\mathrm{CD}^{+}{ }^{+} \mathrm{CD} 25^{+} \mathrm{Foxp}^{+} \mathrm{T}$ cells. Meanwhile, the coincubation supernatants were collected for detection of cytokines level by ELISA as described above.

\section{T cell response primed by $\mathrm{rTsPmy}$ in vivo}

$\mathrm{BALB} / \mathrm{c}$ mice were divided into 3 groups with 4 mice each, and each group was immunized intraperitoneally with $100 \mu \mathrm{g}$ of rTsPmy or the same amount of Sf9 insect cell protein as a non-relevant protein control twice at 2 weeks intervals. Another group of 4 mice were given PBS only. Fourteen days after the final immunization, all mice were sacrificed and the splenocytes were harvested for the analysis of cytokine production and the presence of Th17 cells and Tregs.

For FACS analysis of Th17 cells, the harvested splenocytes were stimulated with $25 \mathrm{ng} / \mathrm{ml}$ phorbol-12myristate-13-acetate (PMA, Sigma-Aldrich, St. Louis, MO, USA), $1 \mu \mathrm{g} / \mathrm{ml}$ ionomycin (Sigma-Aldrich, St. Louis, MO, USA) and $0.66 \mu \mathrm{l} / \mathrm{ml}$ Golgistop ${ }^{\mathrm{ma}}$ (BD Biosciences, San Jose, CA, USA) for $6 \mathrm{~h}$ before cell staining with antiIL-17A-PE-Cyanine7 (eBioscience, San Diego, CA, USA). The culture supernatants were recovered for measuring cytokine release as described above. For detection of Tregs, the harvested splenocytes were directly stained with Mouse Regulatory T Cell Staining Kit \#1 according to the manufacturer's instructions (eBioscience, San Diego, CA, USA).

\section{Statistical analysis}

GraphPad Prism version 6 software (San Diego, CA, USA) was used to analyze statistical data. The results are presented as mean \pm standard deviation. Statistical significance was determined by one-way ANOVA with
Dunnett or Tukey's post-hoc analysis; $P<0.05$ was considered statistically significant.

\section{Results}

Semi-maturation of DCs after rTsPmy stimulation

FACS data demonstrated that both rTsPmy and LPS (positive control) significantly upregulated the expression of CD40 and CD86 on stimulated CD11 $\mathrm{c}^{+}$DCs compared to PBS control (rTsPmy vs PBS: CD40, $t_{D(6)}=2.963, P=0.044$; CD86, $t_{D(6)}=3.106, P=0.037$; LPS vs PBS, CD40, $t_{D(6)}$ $=3.547, P=0.021 ;$ CD86, $t_{D(6)}=4.213, P=0.01$ ) (Fig. 1 ). However, $\mathrm{r} T s$ Pmy and LPS did not stimulate the expression of CD80 and MHCII on CD11c $\mathrm{c}^{+} \mathrm{DCs}\left(\mathrm{CD} 80, F_{(2,6)}=1.209\right.$, $P=0.362$; MHCII, $\left.F_{(2,6)}=0.6119, P=0.573\right)$. These results indicate that $\mathrm{r} T s$ Pmy was able to stimulate the BMDCs to semi-mature status.

\section{Detection of cytokine production of DCs response to rTsPmy}

To further investigate if rTs Pmy stimulates DCs to secrete Th1, Th2, Th17 and regulatory cytokines, IL-1 $\beta$, IL-5, IL-6, IL-10, IL-17A, IL-12 $\mathrm{p}_{70}$, IFN- $\gamma$, TNF- $\alpha$ and TGF- $\beta$ were detected in culture supernatants of antigenstimulated DCs. Compared to the PBS control, IL-1 $\beta$, IL-6, IL- $12 \mathrm{p}_{70}$, IFN- $\gamma$, TNF- $\alpha$ and TGF- $\beta$ were significantly elevated following $\mathrm{rTs}$ Pmy stimulation (IL-1 $\beta$, $t_{D(6)}=24.95, \quad P<0.001 ; \quad$ IL-6, $\quad t_{D(6)}=27.28, \quad P<0.001$; IL-12 $\mathrm{p}_{70}, t_{D(6)}=15.02, P<0.001 ;$ IFN- $\gamma, t_{D(6)}=12.55$, $P<0.001 ; \quad$ TNF- $\alpha, \quad t_{D(6)}=51.19, \quad P<0.001 ; \quad$ TGF- $\beta$, $\left.t_{D(6)}=14.13, P<0.001\right)$, indicating a mixed Th1/Th2/ Treg responses. There was no change in the secretion of IL-5, IL-10 and IL-17A in the supernatants of rTs Pmystimulated DCs (Fig. 2). As a positive control, LPS stimulated secretion of all detected cytokines.

\section{rTsPmy-pulsed DCs activate $T$. spiralis-sensitized $\mathrm{CD}^{+} \mathrm{T}$ cells}

To assess whether rTsPmy-pulsed DCs could activate $T$. spiralis-sensitized $\mathrm{CD} 4^{+} \mathrm{T}$ cells, DCs pulsed with $\mathrm{r} T s$ Pmy for $72 \mathrm{~h}$ were co-cultivated with $T$. spiralis-sensitized CD4 ${ }^{+} \mathrm{T}$ cells from T. spiralis-infected mice for $72 \mathrm{~h}$ in the presence of Con-A. FACS results revealed that $T$. spiralissensitized $\mathrm{CD}^{+} \mathrm{T}$ cells were significantly induced by rTs Pmy-pulsed DCs with a significantly higher proliferation rate compared to PBS incubated DCs (20 folds: $q_{(6)}=$ 14.83, $P<0.001$; 10 folds: $q_{(6)}=20.9, P<0.001$ ) (Fig. 3a, b). LPS-pulsed DCs also boosted $\mathrm{T}$ cell proliferation at a lower rate than that induced by rTsPmy-pulsed DCs.

Cytokine profiling demonstrated that T. spiralis-sensitized $\mathrm{CD} 4^{+} \mathrm{T}$ cells secreted higher level of IL-4, IL-10, TGF- $\beta$ and IL-17A when being incubated with rTsPmypulsed DCs compared to cells incubated with LPS or PBS treated DCs (rTsPmy vs PBS: IL-4, $t_{D(6)}=3.367, P=0.027$; IL-10, $t_{D(6)}=9.988, P<0.001$; TGF- $\beta, t_{D(6)}=10.92, P<0.001$; 


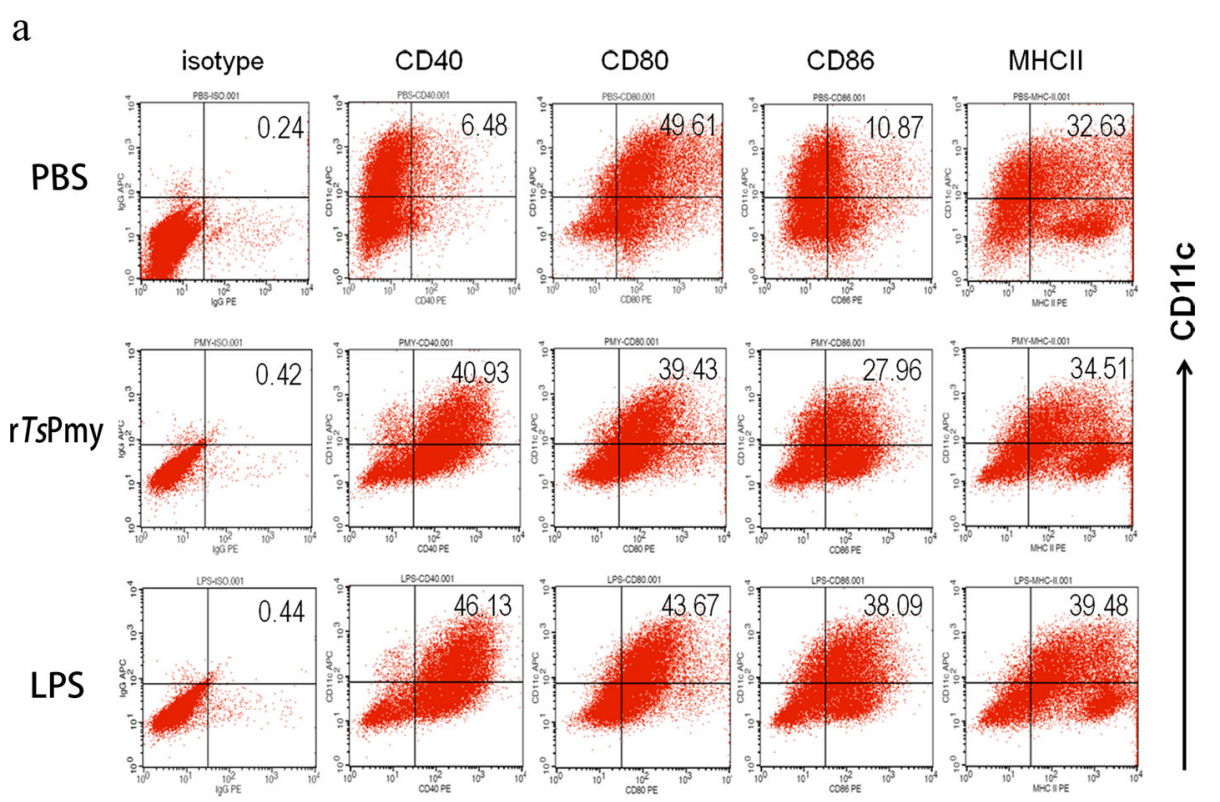

b

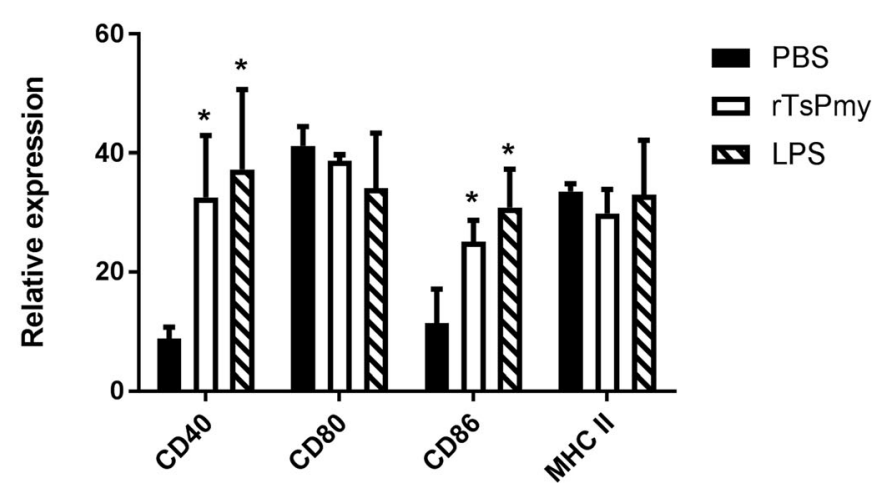

Fig. 1 Expression of surface markers on DCs pulsed with rTsPmy. DCs were pulsed with PBS, rTsPmy or LPS for 48 h. The surface markers CD40, CD80, CD86 and MHCII were sorted by FACS (a). The percentage of each surface marker expression on DCs stimulated with the indicated antigens (b). Data represent means \pm standard deviations of the results from three individual experiments. ${ }^{*} P<0.05$ compared to PBS control

IL-17A, $t_{D(6)}=13.38, P<0.001$ ) (Fig. 3c). However, rTsPmypulsed DCs did not stimulate the secretion of IFN- $\gamma$ in T. spiralis-sensitized $\mathrm{T}$ cells $\left(t_{D(6)}=1.227, P=0.417\right)$. The cytokine profile results support that helminth infections generally polarize the $\mathrm{T}$ cell response towards $\mathrm{Th} 2$, while IL-10 and TGF- $\beta$ might suppress Th1 response and therefore inhibit the production of IFN- $\gamma$. The results of proliferation and cytokine profiling revealed that Ts Pmypulsed DCs are able to activate T cells or boost the memory T cells with Th2 and Treg-related cytokine responses. LPSstimulated DCs only induced some level of IFN $-\gamma$ in CD4 ${ }^{+}$T. spiralis-sensitized $\mathrm{T}$ cells.

\section{rTsPmy-pulsed DCs induces naïve T cells to polarize to Tregs}

In order to determine whether rTsPmy-pulsed DCs induce naïve $\mathrm{CD}^{+} \mathrm{T}$ cell polarization, the $\mathrm{r} T s$ Pmy-treated
DCs were incubated with naïve $\mathrm{T}$ cells isolated from spleens of normal BALB/c mice for $36 \mathrm{~h}$. The FACS results demonstrated that the $\mathrm{CD} 44^{+} \mathrm{CD} 25^{+} \mathrm{Foxp} 3^{+} \mathrm{T}$ cell population was significantly elevated in naïve $\mathrm{T}$ cells cocultivated with rTs Pmy-pulsed DCs compared to PBStreated DCs $\left(t_{D(6)}=4.333, P=0.009\right)$ (Fig. 4a, b), while LPS-pulsed DCs did not obviously affected the population of CD $4^{+} \mathrm{CD} 25^{+} \mathrm{Foxp}^{+} \mathrm{T}$ cells $\left(t_{D(6)}=0.8826, P=0.608\right)$.

In parallel, the culture supernatants were measured for IFN- $\gamma$, IL-4, IL-10, TGF- $\beta$ and IL-17A secretion. The results revealed that $\mathrm{rTs}$ Pmy-pulsed DCs not only induced naïve T cells to secrete cytokine IFN- $\gamma$ (Th1), IL-4 (Th2) and IL-17A (Th17) (IFN- $\gamma, t_{D(6)}=11.23, P<0.001$; IL-17A, $\left.t_{D(6)}=14.68, P<0.001 ; \mathrm{IL}-4, t_{D(6)}=6.626, P=0.001\right)$, but also stimulated high levels of cytokines IL-10 and TGF- $\beta$ secreted mostly by Tregs (IL-10, $t_{D(6)}=32.71, P<0.001$; TGF- $\beta, t_{D(6)}=4.211, P=0.01$ ) (Fig. $4 \mathrm{c}$ ), which is consistent 


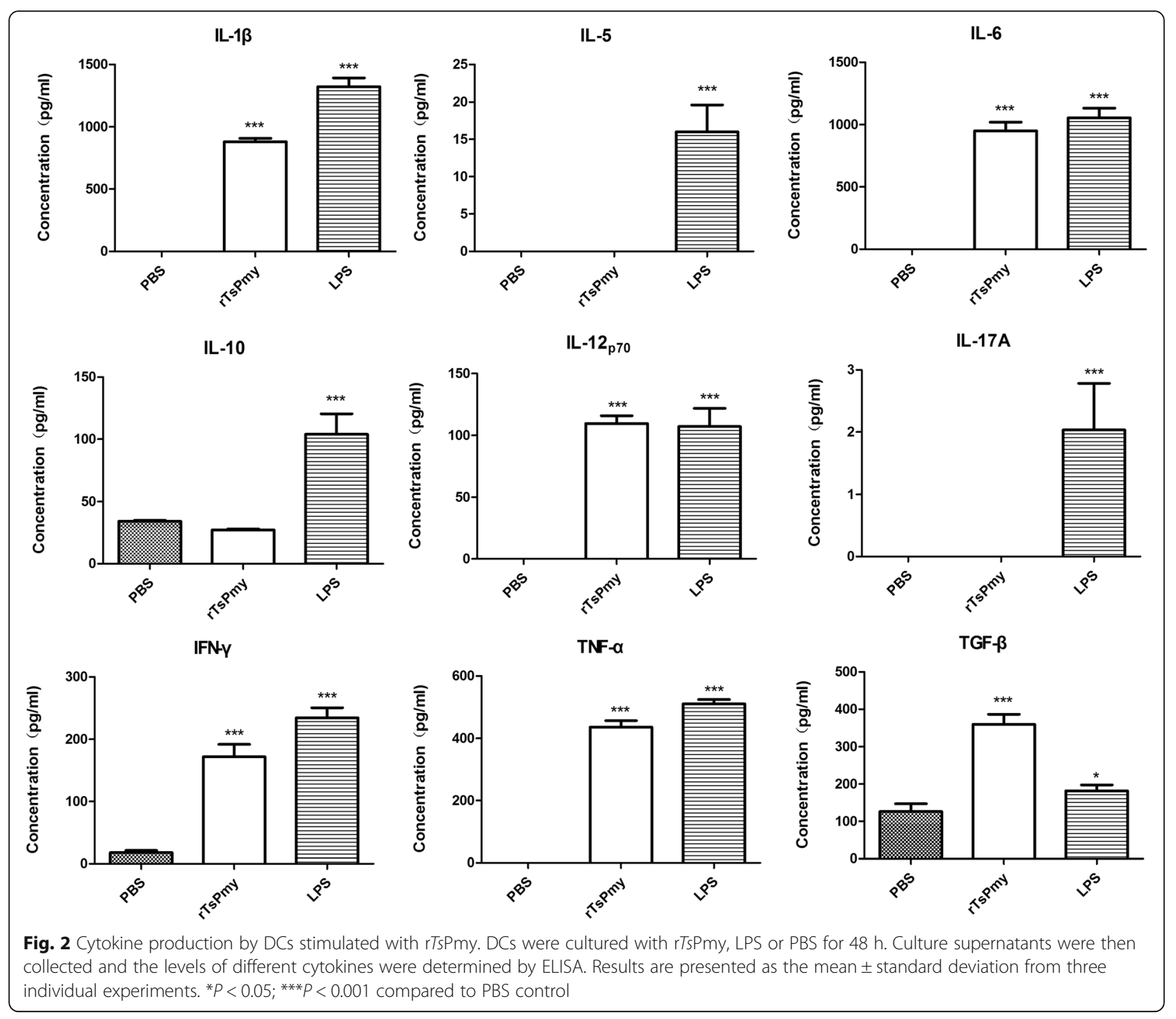

with the increase of Treg population observed by FACS. LPS-pulsed DCs also stimulated naïve T cells to secrete IFN- $\gamma$, IL-10 and IL-17A, but the level was not as high as that induced by rTsPmy-pulsed DCs.

\section{rTsPmy induces Treg in immunized mice}

To confirm if TsPmy enables to induce Treg in vivo, $\mathrm{BALB} / \mathrm{c}$ mice were immunized with $\mathrm{rTs}$ Pmy and the $\mathrm{CD} 4^{+} \mathrm{CD} 25^{+} \mathrm{Foxp}^{+}{ }^{+} \mathrm{T}$ cells were sorted from splenocytes of immunized mice. The FACS results demonstrated that $\mathrm{rTs}$ Pmy immunization did not increase the population of $\mathrm{CD} 44^{+} \mathrm{CD} 25^{+} \mathrm{Foxp}^{+} \mathrm{T}$ cells compared to PBS or non-relevant $\mathrm{Sf} 9$ protein control groups, however, $\mathrm{CD} 4^{+} \mathrm{CD} 25^{-}$Foxp $^{+}{ }^{+} \mathrm{T}$ cells were upregulated ( $\mathrm{r}$ Ts Pmy vs PBS: $\left.t_{D(9)}=3.005, P=0.027\right)$. Interestingly, the Th17 cells were also upregulated in rTs Pmy immunized mice (rTs Pmy vs PBS: $t_{D(9)}=3.402, P=0.014$ ) (Fig. 5a, b). As we know Th17 cells are able to convert T cells into Tregs in mesenchymal stem cell-mediated allograft survival [25].

To further investigate the cytokine profile secreted by splenocytes of rTsPmy immunized mice, splenocytes from immunized mice were isolated and stimulated with PMA/ ionomycin. The different cytokine level in the culture supernatants was detected by ELISA. Results showed IL-4, IL-10, TGF- $\beta$ and IL-17A levels were significantly elevated in cultures of splenocytes from mice immunized with rTs Pmy compared to PBS (IL-4, $t_{D(9)}=7.482, P<0.001$; $\mathrm{IL}-10, t_{D(6)}=5.507, P=0.003$; TGF- $\beta, t_{D(9)}=6.55, P<0.001$; IL-17A, $\left.t_{D(10)}=10.01, P<0.001\right)$ or non-relevant protein (Sf9) injection control groups (IL-4, $t_{D(9)}=6.696, P<0.001$; IL-10, $t_{D(6)}=3.964, \quad P=0.013$; TGF- $\beta, \quad t_{D(9)}=6.554, \quad P<$ 0.001 ; IL-17A, $t_{D(10)}=10.38, P<0.001$ ) (Fig. 5c). There was no change in IFN- $\gamma$ level $\left(F_{(2,7)}=2.162, P=0.186\right)$. The secretions of regulatory cytokine IL-10, TGF- $\beta$ are consistent with the differentiation of $\mathrm{CD} 4^{+} \mathrm{CD} 25^{-} \mathrm{Foxp}^{+}{ }^{+}$Tregs. 
a
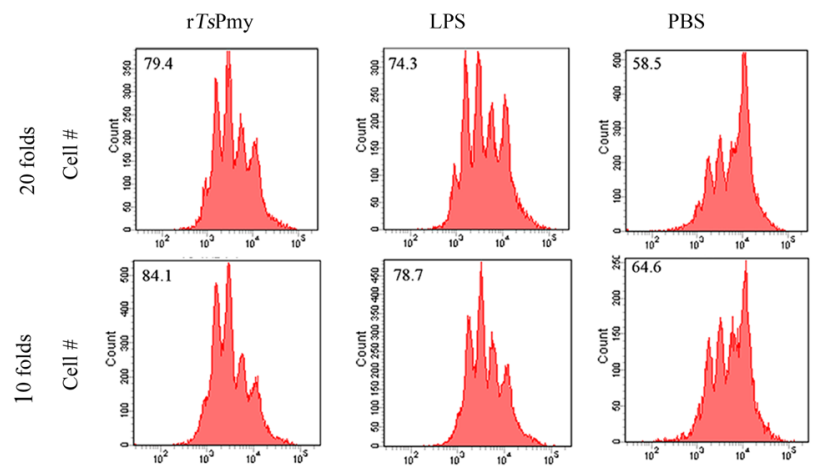

Blank$$
\text { axi }
$$

$\mathrm{b}$

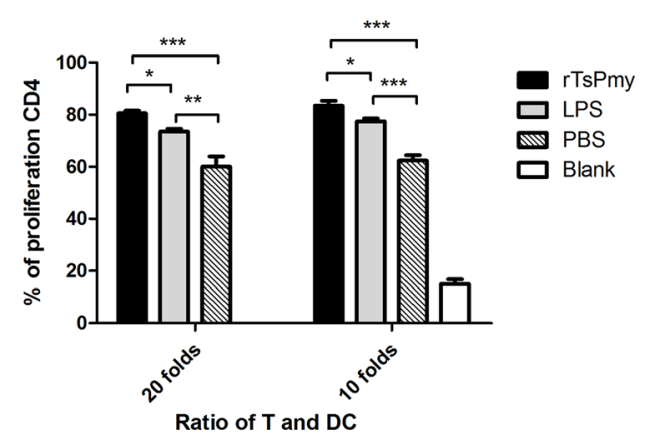

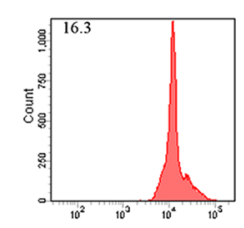

$\mathrm{C}$
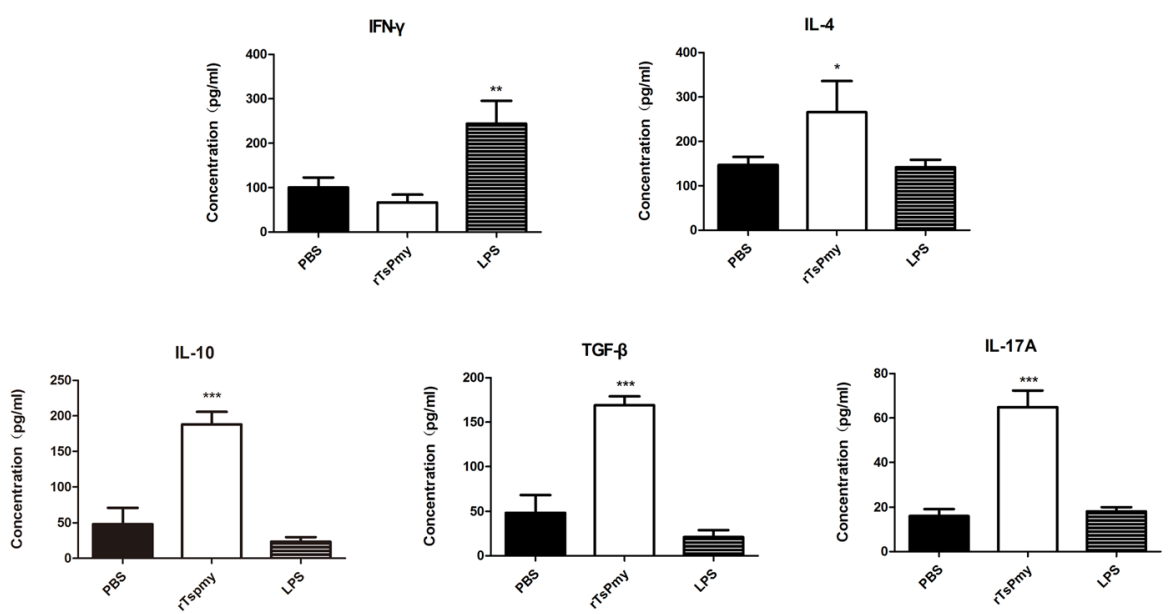

Fig. 3 Proliferation and cytokines secretion of T. spiralis-sensitized CD4 ${ }^{+} T$ cells co-incubated with rTsPmy-pulsed DCs. To assess whether rTsPmy-pulsed DCs enable to stimulate $T$. spiralis-sensitized $C D 4^{+} T$ cells, the $C D 4^{+} T$ cells from splenocytes of $T$. spiralis infected BALB/c mice were incubated with rTsPmy-, LPS- or PBS-treated DCs and the proliferation of co-incubated T cells were determined by CFSE labeling and FACS (a, $\mathbf{b})$. The levels of IFN- $\gamma$, IL-4, IL-10, TGF- $\beta$ and IL-17A in the culture supernatants were measured by ELISA (c). Data are presented as the mean \pm standard deviation from three individual experiments. ${ }^{*} P<0.05 ;{ }^{*} P<0.01 ;{ }^{*} * P<0.001$

\section{Discussion}

During pathogen infections, DCs play a critical role in the induction and orchestration of immune responses. The infection itself induces DC activity and maturation through various families of pattern recognition receptors (PRRs) such as Toll-like receptors [26, 27], and produces different cytokines to prime distinct types of adaptive immune responses [28]. Therefore, DC responses are crucial to control and eliminate the invading pathogens during infection [29]. However, the specific mechanism during interaction between DC and helminthic antigens, especially in the role of helminth immune evasion, are still not quite understood.

We have identified that TsPmy is a strong immunomodulator by interfering with host complement functions as a strategy to evade host innate immune attack 
a

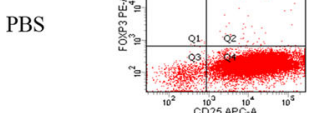

$\operatorname{con}^{10} 25 \mathrm{APCO}^{10^{\circ}} \mathrm{A}$

LPS

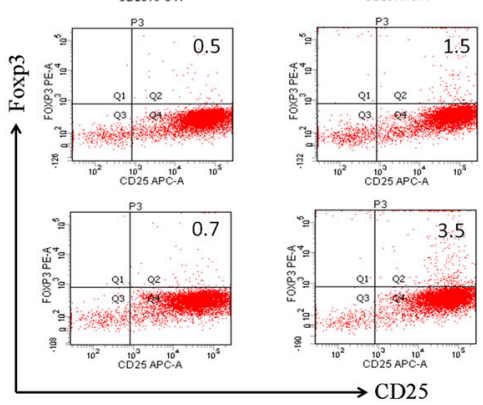

$\mathrm{C}$

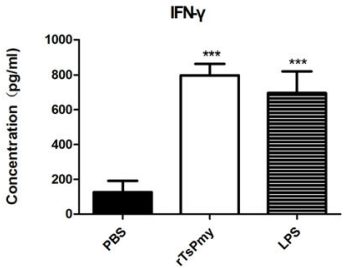

$\mathrm{b}$
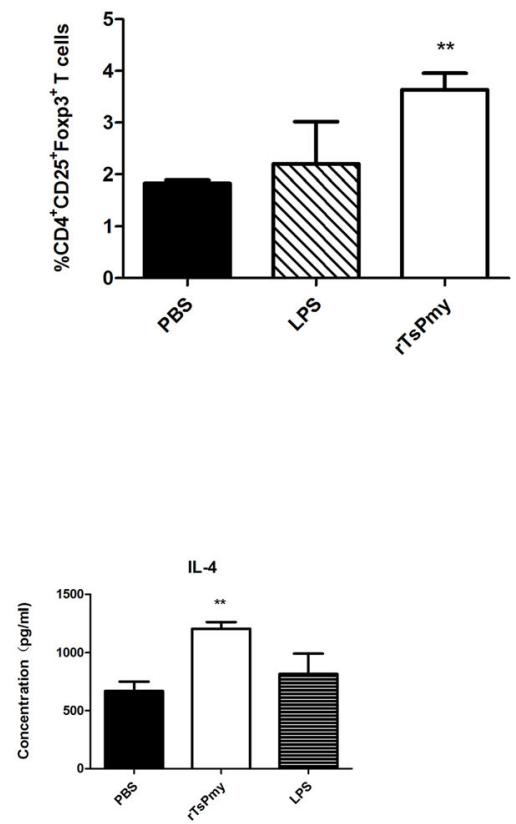
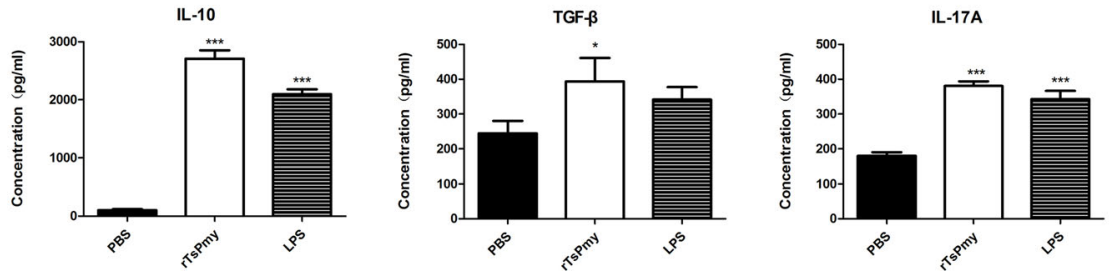

Fig. 4 Induction of $\mathrm{CD}^{+} \mathrm{CD}_{2} 5^{+}$Foxp3 ${ }^{+} \mathrm{T}$ cell population and Treg cytokines in naïve T cells when incubated with rTsPmy-pulsed DCs. The splenocytes isolated from naïve BALB/c mice were incubated with rTsPmy-, LPS- or PBS-treated DCs for $36 \mathrm{~h}$, then labeled with anti-CD4-FITC and anti-CD25-APC and anti-Foxp3-PE for FACS plot analysis (a). The percentage of CD4 ${ }^{+} \mathrm{CD} 25^{+}$Foxp3 ${ }^{+}$cells in $C D 4^{+} \mathrm{T}$ cell population was showed in $\mathbf{b}$. c Cytokine profile of naïve CD4 ${ }^{+} T$ cells incubated with rTsPmy-, LPS- or PBS-treated DCs. The co-incubation supernatants were recovered and measured for secretions of IFN- $\gamma$, IL-4, IL-10, TGF- $\beta$ and IL-17A by ELISA. Data are presented as the mean \pm standard deviation from three individual experiments. ${ }^{*} P<0.05 ;{ }^{*} P<0.01 ;{ }^{* *} P<0.001$ compared to PBS control

in our previous studies [12-15]. In this study, we found that rTs Pmy enabled to stimulate mouse bone marrowderived DCs to express CD40, CD86, but not CD80 and MHCII, on the surface of CD11 $\mathrm{c}^{+}$DCs. rTs Pmy-pusled DCs secreted high level of IL-1 $\beta$, IL-6, IL-12p70, IFN- $\gamma$, TNF- $\alpha$ and TGF- $\beta$, but not for IL-5, IL-10 and IL-17A, indicating $\mathrm{r} T$ s Pmy induces DCs to a semi-mature status in vitro to secrete a mix Th1/Th2/Treg response in cytokine expression. Our results are consistent with other studies that showed parasitic helminth antigens activated DCs to incomplete maturation [22, 30, 31].

When incubating with $T$. spiralis-infected mouse splenocytes, the rTsPmy-pulsed DCs stimulated the T. spiralis-infected mouse $\mathrm{CD}^{+}{ }^{+}$cells to proliferate (Fig. 3a, b), but did not strongerly stimulate the naïve mouse $\mathrm{CD} 4^{+}$cells to proliferate (data not shown), indicating rTsPmy-activated DCs was able to present TsPmy antigen to $\mathrm{T}$ cells previously exposed to T. spiralis infection to activate the TsPmy memory cells. The cytokine profile also confirmed that rTsPmy-pulsed DCs stimulated T. spiralis-infected mouse $\mathrm{CD} 4{ }^{+}$cells to secrete IL- 4 , IL-10, TGF- $\beta$ and IL-17A, but not IFN- $\gamma$, consistent with the Th2-skewed immune response induced by helminth infections [32].

Evasion of host adaptive immunity is key strategy for the survival of parasites in the hostile environment within the host [33, 34]. Many studies have demonstrated both helminths and protozoans create more permissive environments for surviving in hosts by interfering with DCs activity [29, 35]. Helminths and their products have been shown to suppress immune 
a

isotype control PBS

rTsPmy

Sf9

Treg
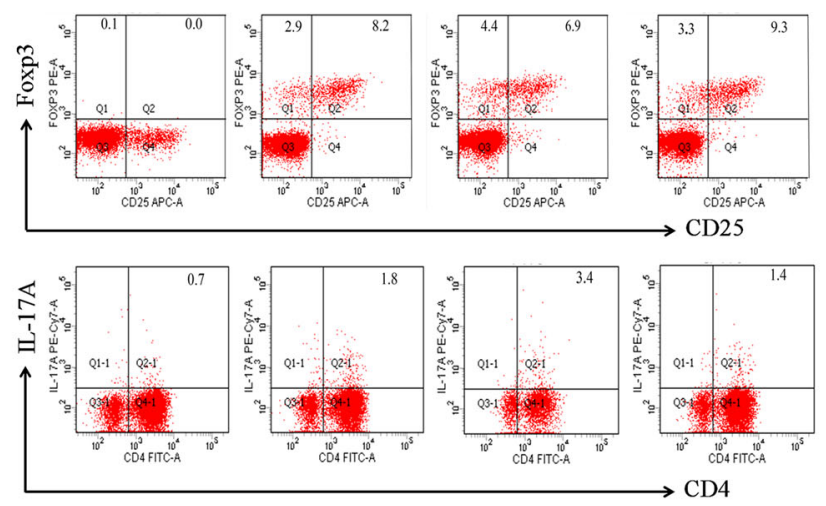

b

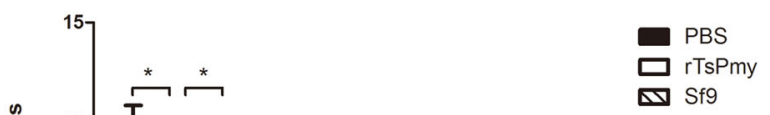

C
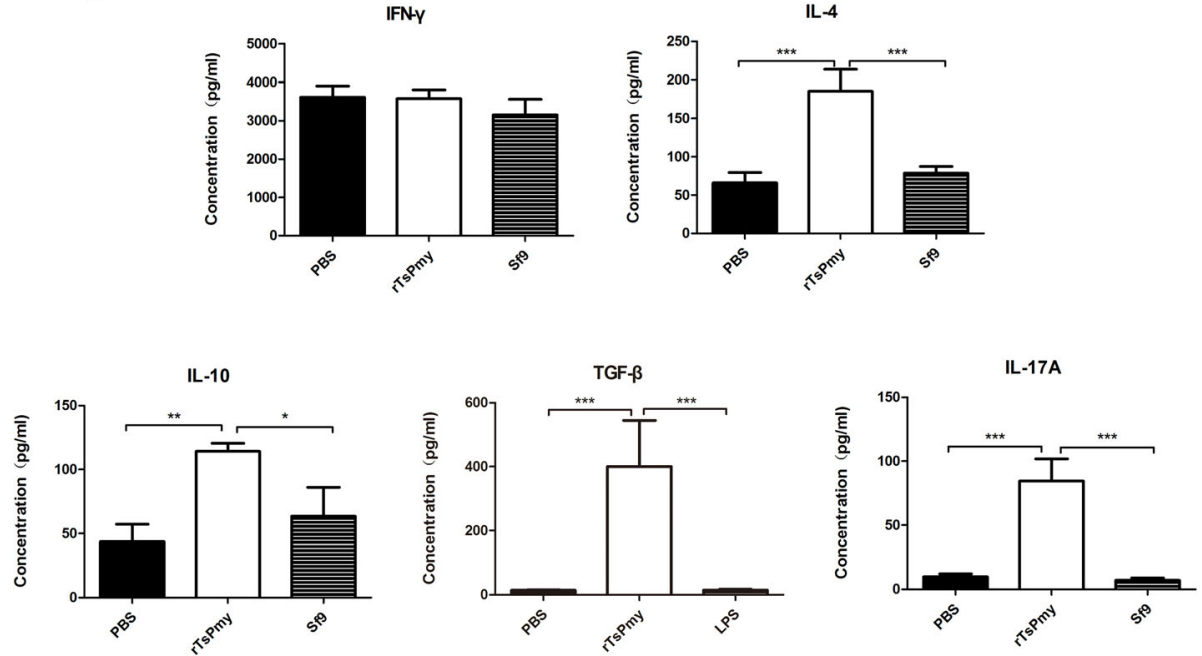

Fig. 5 Tregs and Th17 cell differentiation and cytokines production in splenocytes of mice immunized with rTsPmy. Splenocytes were isolated from mice immunized with rTsPmy or Sf9 protein and sorted for CD4, CD25, Foxp3 and Th17 by FACS (a, b). The different cytokines in splenocyte culture were determined by ELISA (c). Data (means \pm standard deviations) are representative of three independent experiments. ${ }^{*} P<0.05$; ${ }^{* *} P<0.01 ;{ }^{* *} P<0.001$ compared to PBS or Sf9 control as indicated

response of the host by inducing a regulatory network. DCs play a crucial role in this regulatory network, as they can regulate $\mathrm{T}$ cell-mediated effector responses by generating anti-inflammatory cytokines that can lead to induction of regulatory $\mathrm{T}$ cells [36] and promote parasite immune escape by inhibiting parasite-specific immune responses [37]. In order to determine if TsPmy possesses the same immunomodulatory ability to induce 
tolerogenic $\mathrm{DCs}$ so as to stimulate the host $\mathrm{T}$ cell regulatory network, the rTsPmy was incubated with DCs and the rTsPmy-pulsed DCs were co-incubated with naïve mouse $\mathrm{CD}^{+}{ }^{+} \mathrm{T}$ cells. The results showed that TsPmypulsed DCs enabled to induce $\mathrm{CD} 4^{+} \mathrm{CD} 25^{+} \mathrm{Foxp} 3^{+}$Treg cells in vitro associated with higher level of IL-10 and TGF- $\beta$, the cytokines mostly secreted by Tregs [38]. Our results confirmed that TsPmy was able to stimulate tolerogenic DCs that subsequently induce Treg cells to modulate host immune response, possibly through signal passage from $\mathrm{DC}$ to $\mathrm{T}$ cells or TsPmy-pulsed DCsecreted Th1/Th2/Treg cytokines (Fig. 2). Even though $\mathrm{r} T$ S Pmy only induced bone marrow-derived DCs to a semi-mature status, it did not affect their abilities to induce Treg cells, confirming that semi-mature DCs also induce tolerance $[39,40]$. Our results are consistent with other investigations that showed $T$. spiralis excretorysecretory antigen-stimulated dendritic cells alleviated experimental autoimmune encephalomyelitis or DSSinduced colitis through inducing Treg that increased the secretion of IL-4, IL-10 and TGF- $\beta[4,41,42]$. However, rTsPmy immunization only induced $\mathrm{CD} 4^{+} \mathrm{CD} 25^{-} \mathrm{Foxp}^{+}$ $\mathrm{T}$ cells, not $\mathrm{CD} 4^{+} \mathrm{CD} 25^{+} \mathrm{Foxp}^{+}{ }^{+} \mathrm{T}$ cells, in immunized mice. There could be an explanation that experiments represent the situation simplified in vitro, differ from originally existing in live infection. It is possible that rTsPmy stimulates the Tregs through multiple channels in vivo except for inducing tolerogenic DCs (such as CTLA-4, TGF- $\beta$, IL-10, and GITR). Naïve T cells can be converted to a Treg phenotype by culture with CTLA-4Ig [43]. IL-6 can convert CD $4^{+} \mathrm{CD} 25^{+} \mathrm{Foxp}^{+}{ }^{+}$Tregs but not $\mathrm{CD} 4^{+} \mathrm{CD} 25^{-} \mathrm{Foxp}^{+}$Tregs to Th17 cells [44]. The reasons why $\mathrm{CD} 4^{+} \mathrm{CD} 25^{-} \mathrm{Foxp}^{+}{ }^{+}$Tregs, not $\mathrm{CD} 4^{+} \mathrm{CD} 25$ ${ }^{+}$Foxp $3^{+}$Tregs were induced with $\mathrm{r} T s$ Pmy immunization need to be further studied. Nevertheless, Foxp3 expression, rather than CD25 expression is essential for Treg's activity [45]. CD4 $4^{+} \mathrm{CD} 25^{-} \mathrm{Foxp}^{+} \mathrm{T}$ cells also showed suppressive activity $[45,46]$. Actually, during $T$. spiralis chronic infection, $\mathrm{CD} 4{ }^{+} \mathrm{CD} 25^{-}$effector $\mathrm{T}$ cells control inflammation, rather than $\mathrm{CD} 44^{+} \mathrm{CD} 25^{+}$Tregs [47]. It was an interesting finding that $\mathrm{r}$ Ts Pmy immunization in vivo generated $\mathrm{CD} 4^{+} \mathrm{CD} 25^{-} \mathrm{Foxp} 3^{+}$Tregs that is different from in vitro stimulation of $\mathrm{CD} 4^{+} \mathrm{CD} 25^{+} \mathrm{Foxp} 3^{+}$ Tregs via inducing tolerogenic DCs.

In addition, in this study we identified that rTsPmypulsed DCs induced T. spiralis-infected mouse $\mathrm{CD} 4^{+}$or naïve $\mathrm{CD} 4^{+} \mathrm{T}$ cells to produce high level of IL-17A. Mice immunized with rTsPmy in vivo also induced the generation of Th17 cells. Even though Th17 cells have been considered to be pro-inflammatory and induce autoimmunity [44], the generation of Th17 cells during Schistosoma japonicum infection in C57BL/6 mice has determined to induce suppressive immunity to schistosome infection [48]. Interestingly, some Foxp ${ }^{+}$Treg cells could convert to IL-17 $7^{+} \mathrm{T}$ cells upon co-culture with dendritic cells selectively activated by dectin-1, a C-type lectin receptor involved in fungal recognition [49]. The conversion of Treg cells into Th17 cells may help restrain infections with specific fungi or other pathogens [50]. The flexibility between induced regulatory T cells and Th17 cells may affect the differentiation of $\mathrm{CD} 4^{+} \mathrm{T}$ cells and therefore may alter the direction of immune response [44, 51]. However, the relationship between the Treg and Th17 responses in T. spiralis infection remains unclear.

Together with our previous studies, our results further suggest the immunomodulatory function of $T$. spiralis paramyosin, which interacts with dendritic cells and stimulates regulatory $\mathrm{T}$ cells and Th17 cells. The data further support that Ts Pmy plays an important role in the immunomodulation of host immune response as a survival strategy, and is therefore a good candidate for vaccine development against trichinellosis. It is also possible to use rTs Pmy as a therapeutic reagent for autoimmune or allergic diseases by taking advantage of its stimulating regulatory network of the immune system.

\section{Conclusions}

Our results showed that TsPmy is able to activate mouse bone marrow-derived DCs to semi-mature status characterized by expressing CD40 and CD86, without CD80 and MHCII on the surface of CD11 $\mathrm{c}^{+} \mathrm{DCs}$. The semi-matured Ts Pmy-pulsed DCs were able to stimulate T. spiralis-sensitized $\mathrm{CD}_{4}^{+} \mathrm{T}$ cells to proliferate associated with the secretion of IL-10 and TGF- $\beta$ produced mostly by Treg cells. Incubation of TsPmy-pulsed DCs with naïve $\mathrm{CD} 4^{+}$ splenocytes polarized the latter to $\mathrm{CD} 44^{+} \mathrm{CD} 25^{+}$Foxp $3^{+}$ Tregs. However, mice immunized with rTsPmy only induce the $\mathrm{CD} 4^{+} \mathrm{CD} 25^{-} \mathrm{Foxp}^{+} \mathrm{T}$ cell population, associated with high level of IL-10 and TGF- $\beta$. rTsPmy also induced Th17 response, possibly converted from Foxp $3^{+}$Tregs. During T. spiralis infection, TsPmy plays an important role in modulating the host immune system by stimulating DCs to promote differentiation of regulatory $\mathrm{T}$ cells, in addition to binding to components of the host complement cascade, as survival strategies to live in host.

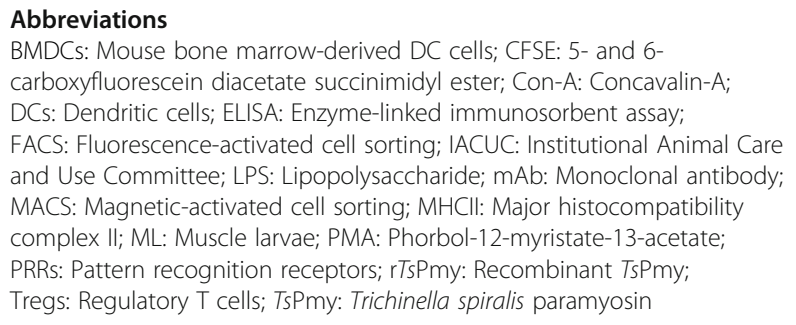

\section{Acknowledgments}

We thank Bin Zhan and Yuli Cheng, Jing Yang, Xiaohuan Wang, Ran Sun, Limei Zhao and Rui Zhang for their technical assistance and helpful suggestions. 


\section{Funding}

This study was supported by grants from the National Natural Science Foundation of China $(81371837,81401681)$, Natural Science Foundation of Beijing (7144192). Grant No.81371837 was used to support experiment reagents and publication. Grants No. 81401681 and No. 7144192 were used to purchase experiment animals, reagents and other relevant materials.

\section{Availability of data and materials}

The data supporting the conclusions of this article are included within the article.

\section{Authors' contributions}

KG and XMS performed the experiments. YG, ZXW and JJH performed some of the experiments. The manuscript was written by KG and XMS. XPZ revised the manuscript. XMS and XPZ designed the study. All authors read and approved the final manuscript.

\section{Competing interests}

The authors declare that they have no competing interests.

\section{Consent for publication}

\section{Not applicable.}

\section{Ethics approval and consent to participate}

All animal experimentation was carried out in compliance with Capital Medical University IACUC. Capital Medical University ethics committee approved the study and the committee's reference numbers were AEEI-2015-183 and AEEI-2015-184.

Received: 31 August 2016 Accepted: 24 October 2016 Published online: 04 November 2016

\section{References}

1. Dupouy-Camet J. Trichinellosis: a worldwide zoonosis. Vet Parasitol. 2000;93(3-4):191-200.

2. Wilson NO, Hall RL, Montgomery SP, Jones JL. Trichinellosis surveillance United States, 2008-2012. MMWR Surveill Summ. 2015:64(1):1-8.

3. Yang J, Pan W, Sun X, Zhao X, Yuan G, Sun Q, et al. Immunoproteomic profile of Trichinella spiralis adult worm proteins recognized by early infection sera. Parasit Vectors. 2015;8:20. doi:10.1186/s13071-015-0641-8.

4. Yang $X$, Yang $Y$, Wang $Y$, Zhan B, Gu Y, Cheng $Y$, et al. Excretory/secretory products from Trichinella spiralis adult worms ameliorate DSS-induced colitis in mice. PLoS One. 2014;9(5):e96454. doi:10.1371/journal.pone.0096454.

5. Cancela M, Carmona C, Rossi S, Frangione B, Goni F, Berasain P. Purification, characterization, and immunolocalization of paramyosin from the adult stage of Fasciola hepatica. Parasitol Res. 2004;92(6):441-8. doi:10.1007/s00436-003-1059-3.

6. Loukas A, Jones MK, King LT, Brindley PJ, McManus DP. Receptor for Fc on the surfaces of schistosomes. Infect Immun. 2001;69(6):3646-51. doi:10.1128/IAl.69.6.3646-3651.2001

7. Muhlschlegel F, Sygulla L, Frosch P, Massetti P, Frosch M. Paramyosin of Echinococcus granulosus: CDNA sequence and characterization of a tegumental antigen. Parasitol Res. 1993;79(8):660-6.

8. Gazarian KG, Solis CF, Gazarian TG, Rowley M, Laclette JP. Synthetic peptidetargeted selection of phage display mimotopes highlights immunogenic features of alpha-helical vs non-helical epitopes of Taenia solium paramyosin: implications for parasite- and host-protective roles of the protein. Peptides. 2012;34(1):232-41. doi:10.1016/j.peptides.2011.10.003.

9. Deng J, Gold D, LoVerde PT, Fishelson Z. Inhibition of the complement membrane attack complex by Schistosoma mansoni paramyosin. Infect Immun. 2003;71(11):6402-10.

10. Wang $X$, Chen W, Lv X, Tian Y, Men J, Zhang X, et al. Identification and characterization of paramyosin from cyst wall of metacercariae implicated protective efficacy against Clonorchis sinensis infection. PLoS One. 2012;7(3):e33703. doi:10.1371/journal.pone.0033703.

11. Yang J, Yang Y, Gu Y, Li Q, Wei J, Wang S, et al. Identification and characterization of a full-length cDNA encoding paramyosin of Trichinella spiralis. Biochem Biophys Res Commun. 2008;365(3):528-33. doi:10.1016/j. bbrc.2007.11.012.

12. Zhang Z, Yang J, Wei J, Yang $Y$, Chen $X$, Zhao $X$, et al. Trichinella spiralis paramyosin binds to $C 8$ and $C 9$ and protects the tissue-dwelling nematode from being attacked by host complement. PLoS Negl Trop Dis. 2011;5(7): e1225. doi:10.1371/journal.pntd.0001225.

13. Zhao X, Hao Y, Yang J, Gu Y, Zhu X. Mapping of the complement C9 binding domain on Trichinella spiralis paramyosin. Parasit Vectors. 2014;7:80. doi:10.1186/1756-3305-7-80.

14. Hao Y, Zhao X, Yang J, Gu Y, Sun R, Zhu X. Monoclonal antibody targeting complement $C 9$ binding domain of Trichinella spiralis paramyosin impairs the viability of Trichinella infective larvae in the presence of complement. Parasit Vectors. 2014;7:313. doi:10.1186/1756-3305-7-313.

15. Sun R, Zhao X, Wang Z, Yang J, Zhao L, Zhan B, et al. Trichinella spiralis paramyosin binds human complement $\mathrm{Clq}$ and inhibits classical complement Activation. PLoS Negl Trop Dis. 2015;9(12):e0004310. doi:10.1371/journal.pntd.0004310.

16. Yang J, Gu Y, Yang Y, Wei J, Wang S, Cui S, et al. Trichinella spiralis: immune response and protective immunity elicited by recombinant paramyosin formulated with different adjuvants. Exp Parasitol. 2010;124(4):403-8. doi:10.1016/j.exppara.2009.12.010.

17. Gu Y, Wei J, Yang J, Huang J, Yang X, Zhu X. Protective immunity against Trichinella spiralis infection induced by a multi-epitope vaccine in a murine model. PLoS One. 2013;8(10):e77238. doi:10.1371/journal.pone.0077238.

18. Wei J, Gu Y, Yang J, Yang Y, Wang S, Cui S, et al. Identification and characterization of protective epitope of Trichinella spiralis paramyosin. Vaccine. 2011;29(17):3162-8. doi:10.1016/j.vaccine.2011.02.072.

19. Gu Y, Huang J, Wang X, Wang L, Yang J, Zhan B, et al. Identification and characterization of CD4+ T cell epitopes present in Trichinella spiralis paramyosin. Vet Parasitol. 2016; doi: 10.1016/j.vetpar.2016.06.022.

20. Chen X, Yang Y, Yang J, Zhang Z, Zhu X. RNAi-mediated silencing of paramyosin expression in Trichinella spiralis results in impaired viability of the parasite. PLoS One. 2012;7(11):e49913. doi:10.1371/journal.pone.0049913.

21. Aranzamendi $C$, Fransen $F$, Langelaar $M$, Franssen $F$, van der Ley $P$, van Putten JP, et al. Trichinella spiralis-secreted products modulate DC functionality and expand regulatory T cells in vitro. Parasite Immunol. 2012;34(4):210-23. doi:10.1111/j.1365-3024.2012.01353.x.

22. Ilic N, Worthington JJ, Gruden-Movsesijan A, Travis MA, SofronicMilosavljevic L, Grencis RK. Trichinella spiralis antigens prime mixed Th1/Th2 response but do not induce de novo generation of Foxp3+ T cells in vitro. Parasite Immunol. 2011;33(10):572-82. doi:10.1111/j.1365-3024.2011.01322.x.

23. Daro E, Pulendran B, Brasel K, Teepe M, Pettit D, Lynch DH, et al. Polyethylene glycol-modified GM-CSF expands CD11b(high)CD11c(high) but notCD11b(low)CD11c(high) murine dendritic cells in vivo: a comparative analysis with Flt3 ligand. J Immunol. 2000;165(1):49-58.

24. Li Y, Kurlander RJ. Comparison of anti-CD3 and anti-CD28-coated beads with soluble anti-CD3 for expanding human T cells: differing impact on CD8 T cell phenotype and responsiveness to restimulation. J Transl Med. 2010;8:104. doi:10.1186/1479-5876-8-104.

25. Obermajer N, Popp FC, Soeder Y, Haarer J, Geissler EK, Schlitt HJ, et al. Conversion of Th17 into IL-17A(neg) regulatory $T$ cells: a novel mechanism in prolonged allograft survival promoted by mesenchymal stem cellsupported minimized immunosuppressive therapy. J Immunol. 2014;193(10): 4988-99. doi:10.4049/jimmunol.1401776.

26. Terrazas CA, Alcantara-Hernandez M, Bonifaz L, Terrazas LI, Satoskar AR. Helminth-excreted/secreted products are recognized by multiple receptors on DCs to block the TLR response and bias Th2 polarization in a CRAF dependent pathway. FASEB J. 2013;27(11):4547-60. doi:10.1096/fj.13-228932.

27. Hu W, Jain A, Gao Y, Dozmorov IM, Mandraju R, Wakeland EK, et al. Differential outcome of TRIF-mediated signaling in TLR4 and TLR3 induced DC maturation. Proc Natl Acad Sci U S A. 2015;112(45):13994-9. doi:10.1073/ pnas. 1510760112.

28. Reis e Sousa C, Diebold SD, Edwards AD, Rogers N, Schulz O, Sporri R. Regulation of dendritic cell function by microbial stimuli. Pathol Biol (Paris). 2003;51(2):67-8

29. Terrazas CA, Terrazas LI, Gomez-Garcia L. Modulation of dendritic cell responses by parasites: a common strategy to survive. J Biomed Biotechnol. 2010:2010:357106

30. van Riet E, Hartgers FC, Yazdanbakhsh M. Chronic helminth infections induce immunomodulation: consequences and mechanisms. Immunobiology. 2007;212(6):475-90.

31. Ilic N, Colic M, Gruden-movsesijan A, Majstorovic I, Vasilev S, SofronicMilosavljevic L. Characterization of rat bone marrow dendritic cells initially primed by Trichinella spiralis antigens. Parasite Immunol. 2008;30(9):491-5. 
32. McKee AS, Pearce EJ. CD25 + CD4+ cells contribute to Th2 polarization during helminth infection by suppressing Th1 response development. J Immunol. 2004;173(2):1224-31.

33. Schmid-Hempel P. Parasite immune evasion: a momentous molecular war. Trends Ecol Evol. 2008;23(6):318-26.

34. Layland LE, Ajendra J, Ritter M, Wiszniewsky A, Hoerauf A, Hubner MP. Development of patent Litomosoides sigmodontis infections in semisusceptible C57BL/6 mice in the absence of adaptive immune responses. Parasit Vectors. 2015;8:396.

35. Jangpatarapongsa K, Chootong P, Sattabongkot J, Chotivanich K, Sirichaisinthop J, Tungpradabkul S, et al. Plasmodium vivax parasites alter the balance of myeloid and plasmacytoid dendritic cells and the induction of regulatory T cells. Eur J Immunol. 2008;38(10):2697-705.

36. Maldonado RA, von Andrian UH. How tolerogenic dendritic cells induce regulatory T cells. Adv Immunol. 2010;108:111-65.

37. Wilson MS, Taylor MD, Balic A, Finney CA, Lamb JR, Maizels RM. Suppression of allergic airway inflammation by helminth-induced regulatory $T$ cells. J Exp Med. 2005;202(9):1199-212.

38. Fontenot JD, Gavin MA, Rudensky AY. Foxp3 programs the development and function of CD4 + CD25+ regulatory T cells. Nat Immunol. 2003;4(4): 330-6.

39. Lutz MB, Schuler G. Immature, semi-mature and fully mature dendritic cells: which signals induce tolerance or immunity? Trends Immunol. 2002;23(9): 445-9.

40. Lutz MB, Kurts $C$. Induction of peripheral CD4+ T-cell tolerance and CD8+ Tcell cross-tolerance by dendritic cells. Eur J Immunol. 2009:39(9):2325-30.

41. Sofronic-Milosavljevic LJ, Radovic I, llic N, Majstorovic I, Cvetkovic J, GrudenMovsesijan A. Application of dendritic cells stimulated with Trichinella spiralis excretory-secretory antigens alleviates experimental autoimmune encephalomyelitis. Med Microbiol Immunol. 2013;202(3):239-49.

42. Gruden-Movsesijan A, llic N, Mostarica-Stojkovic M, Stosic-Grujicic S, Milic M, Sofronic-Milosavljevic L. Mechanisms of modulation of experimental autoimmune encephalomyelitis by chronic Trichinella spiralis infection in Dark Agouti rats. Parasite Immunol. 2010;32(6):450-9.

43. Razmara M, Hilliard B, Ziarani AK, Chen YH, Tykocinski ML. CTLA-4 x Ig converts naive CD4+ CD25- $T$ cells into $C D 4+C D 25+$ regulatory $T$ cells. Int Immunol. 2008;20(4):471-83.

44. Bettelli E, Carrier Y, Gao W, Korn T, Strom TB, Oukka M, et al. Reciprocal developmental pathways for the generation of pathogenic effector $\mathrm{TH} 17$ and regulatory T cells. Nature. 2006;441(7090):235-8.

45. Fontenot JD, Rasmussen JP, Williams LM, Dooley JL, Farr AG, Rudensky AY. Regulatory $T$ cell lineage specification by the forkhead transcription factor foxp3. Immunity. 2005;22(3):329-41.

46. Ono M, Shimizu J, Miyachi Y, Sakaguchi S. Control of autoimmune myocarditis and multiorgan inflammation by glucocorticoid-induced TNF receptor family-related protein(high), Foxp3-expressing CD25+ and CD25regulatory T cells. J Immunol. 2006;176(8):4748-56.

47. Beiting DP, Gagliardo LF, Hesse M, Bliss SK, Meskill D, Appleton JA. Coordinated control of immunity to muscle stage Trichinella spiralis by IL-10, regulatory T cells, and TGF-beta. J Immunol. 2007:178(2):1039-47.

48. Wen X, He L, Chi Y, Zhou S, Hoellwarth J, Zhang C, et al. Dynamics of Th17 cells and their role in Schistosoma japonicum infection in C57BL/6 mice. PLoS Negl Trop Dis. 2011;5(11):e1399.

49. Osorio F, LeibundGut-Landmann S, Lochner M, Lahl K, Sparwasser T, Eberl G, et al. DC activated via dectin-1 convert Treg into IL-17 producers. Eur J Immunol. 2008;38(12):3274-81.

50. Peck A, Mellins ED. Precarious balance: Th17 cells in host defense. Infect Immun. 2010;78(1):32-8.

51. Zhou L, Chong MM, Littman DR. Plasticity of CD4+ T cell lineage differentiation. Immunity. 2009;30(5):646-55.

\section{Submit your next manuscript to BioMed Central and we will help you at every step:}

- We accept pre-submission inquiries

- Our selector tool helps you to find the most relevant journal

- We provide round the clock customer support

- Convenient online submission

- Thorough peer review

- Inclusion in PubMed and all major indexing services

- Maximum visibility for your research

Submit your manuscript at www.biomedcentral.com/submit
Biomed Central 